stick with which to measure their transactions, they have been put on notice that the protection of their own funds is not enough, and theirs is the responsibility of creating a financial structure which will not unduly jeopardize creditors in the event of the subsidiary's insolvency.

\title{
THE TRUSTING TRUSTEE: MOSSER V. DARROW
}

During his life on the bench, possibly every judge has to face a number of situations, best characterized as "painful." It is not that the law is wrong, nor even that the losing party has strong equities on his side. Rather, some poor fellow, through some form of foolish behavior has become involved in a terrible fix. He's not a bad guy - he may even be a good one. And the judge may be tempted to help extricate him from this mess. At times, it can be done; the precedent is there. At times, the circumstances are such that neither juggling judicial concepts nor realigning cases will ever ring true. In effect, this was the situation before the Court of Appeals for the Seventh Circuit in Darrow v. Mosser. ${ }^{1}$

These were the facts. In a 1935 reorganization proceeding, Judge Holly, a respected jurist, had appointed as trustee, Mr. Darrow, son of the eminent attorney but not an attorney himself. The debtor-trusts were formed in 1930 to hold the stock of several building corporations, each with bonds outstanding. Mr. Darrow retained a gentleman named Kulp and a lady named Johnsonpromoters of the subsidiaries - with the express understanding that they would be free to trade in the subsidiaries' securities. And trade they did.

Mr. Darrow had inaugurated a plan of bond retirement, and he relied on the advice of the lady named Johnson to execute this plan. Miss Johnson found herself in a not unhappy position. She knew at what prices the bondholders would sell as well as the prices that the trust would pay. Miss Johnson did not let this information go to waste. Free competition may presuppose a knowing seller and a knowing buyer, but Miss Johnson was no theoretical economist. She left the parties in their abysmal ignorance and, whenever the occasion permitted, bought from the bondholders and sold to the trust or the public at a tidy profit.

Mr. Darrow's part in this little drama was a rather perplexing one. While he believed that it would be a "dangerous practice" for him to sell securities to the trust, ${ }^{2}$ he apparently had no objection to Mr. Kulp and Miss Johnson doing so.

1184 F. 2 d 1 (C.A. 7th, 1950); Mosser v. Darrow, 341 U.S. 267 (1951).

${ }^{2}$ Transcript of Record before the Supreme Court at 341. "I thought that I had a perfect right to buy and sell securities to the trusts or anybody else if . . I I did not charge them more than they were paying for securites of the same kind at the same time.

"It was my opinion that I had a right to deal in these securities selling them either to the trusts or subsidiaries and earn a profit (I [personally] didn't do any trading out of considera- 
These two grass-roots economists did most of their dealing through a trading company named Colonial, and Mr. Darrow felt that doing business with Colonial was just like doing business with any house "in New York or some other place in Chicago."3

Again, Darrow felt that the price was none of his business. ${ }^{4}$ There can be no doubt that Miss Johnson agreed with him. She must have nodded approval when he said, "I thought and still think that the price at which Miss Johnson sold bonds to me was a personal matter and I did not inquire into such personal matters." It is not surprising then, that Mr. Darrow did not concern himself with the profits that Kulp, Johnson and entourage had made; he thought it was none of his business.

Lest suspicion of Mr. Darrow be somewhat aroused, one must hasten to point out that the Special Master found that Darrow did not personally share in his employees' profits. On several occasions, when the trust had insufficient funds, Mr. Darrow used his own money to purchase bonds which he resold to the trust at cost. ${ }^{6}$ Furthermore, he refused to accept the fees paid to him as president of each subsidiary and instead relinquished them to the trust. ${ }^{7}$ The amazing divergence between the standards which Mr. Darrow placed on himself, and the freefor-all which he permitted his employees, indicates that the gentleman did not take his job very seriously.

Mr. Darrow had placed the courts in an uncomfortable position. Here was a fellow, honest and upright, though perhaps a bit naïve, who had apparently blindfolded himself while his employees played ring-around-the-rosy with other people's money. Probably he meant no harm; certainly, he made no gain. But the damage was done, and it looked as if $\mathrm{Mr}$. Darrow was stuck with the bill.

The Court of Appeals thought otherwise. It was true that no direct precedent could be found, ${ }^{8}$ but this was undoubtedly due to the fact that no one had ever doubted that a man in Darrow's position would be held liable. Nevertheless, the

tion for Judge Holly and my father). I realized it would be a dangerous practice because somebody would try to show that I had been unreasonable with my dealings in the trusts. . . .

"Whether the profit they realized in transactions with me was reasonable or not was of no consequence to me. The important thing was that I did not pay them more than I was paying anyone else."

${ }^{3}$ Ibid., at 338-39.

- Ibid., at 209. "I never made any inquiry when and where people got the bonds I purchased or what they paid for them. I never made any effort at all to ascertain and did not know whether Kulp, Johnson or Colonial made profits out of these bonds that I bought from them. Colonial books were available but I did not examine them. It is easily possible that Colonial, Johnson, and Kulp made profits on these transactions, and I didn't think it was any of my business."

5 Tbid., at 211. ${ }^{6}$ Ibid., at 207. ${ }^{7}$ Ibid., at 203.

8 The following cases in the opinion can be distinguished on their facts: In re Marcus, $2 \mathrm{~F}$. Supp. 524 (W.D., 1932) (thefts by the trustees' employees); Evans v. Williams, 276 Fed. 650 (C.A. 6th, 1921) (surcharge for net operating loss); Speight v. Gaunt, 22 Ch. D. 727 (1883) (surcharge for payment on a spurious "bought note"). 
court chose to ignore what everyone else considered obvious. It caricatured the rule of the prudent man and found, surprise of surprises, that Mr. Darrow was a "prudent man."

Unfortunately the Supreme Court ${ }^{10}$ refused to swallow this argument. The majority pointed out that talking in terms of the negligence test, the "prudent man" rule was irrelevant; Mr. Darrow had explicitly authorized his employee's conduct. Justice Black proposed a compromise: Darrow was wrong, but let's give the rule prospective application only. ${ }^{11}$ But the rest of the Court voted him down. Reversing the Court of Appeals, the Supreme Court said, in effect, that a trustee may not authorize his employees to act in a manner forbidden to him. Undoubtedly, the court was right. But nobody seemed very happy about itleast of all, Mr. Darrow.

\section{FORCING PREFERRED DIVIDENDS: THE CHICAGO GREAT WESTERN SETTLEMENT}

The declaration of corporate dividends is usually considered a matter within the sound discretion of the corporate directors. Courts have traditionally been reluctant to interfere with this discretion unless it is shown that the action of the directors in declaring or refusing to declare a dividend is fraudulent, in bad faith, oppressive, or clearly and extremely unreasonable. ${ }^{1}$ Thus stockholders suing to compel a declaration of dividends must meet a severe burden of proof. The probability of their success is diminished by two practical considerations. One is that the principal sources of evidence are the defendant corporation's officers and directors. The other is that the defendants are backed by the corporate pocketbook and prestige.

However, the rarity of recorded stockholder success in dividend cases does not necessarily indicate that the stockholder suit fails to offer adequate protection to those who are entitled to relief. Corporate transactions that are used to

- It may be noted that two circumstances around which the rule was formulated have changed. One is a growing expectation and demand that experts live up to their vaunted expertise and be judged, accordingly, by a higher standard than that of the prudent man. The other is that fiduciaries are now compensated for their services. See, e.g., Speight v. Gaunt, 22 Ch. D. 727 (1883) (non-compensation of fiduciaries). This payment can be regarded, at least in part, as remuneration for the added responsibility which the hired expert is expected to assume.

${ }^{10}$ Mosser v. Darrow, 341 U.S. 267 (1951).

11 Great Northern Ry. Co.v. Sunburst Oil and Refining Co., 287 U.S. 358 (1932), cited by Justice Back, merely held that no Federal Constitutional provision compelled state courts to give retroactive effect to their decisions. Refusing to give retroactive application can be justified when a case is overruled on which people have relied, or where a rule is formed which differs from established expectations. The Mosser case neither overruled any case nor defeated any established expectations.

${ }^{1}$ See Minority Shareholder Suits to Compel Declaration of Dividends, 64 Harv. L. Rev. 299 (1950); Dividend Rights of Non-Cumulative Preferred Stock, 61 Yale L.J. 245 (1952). 